\title{
Humic acid, an effective amendment used for amelioration of Phosphatic fertilizer and enhancing maize yield
}

\author{
Zaheer Ahmad ${ }^{1}$, Qudrat Ullah Khan ${ }^{1 *}$, Abdul Qadoos ${ }^{2}$, Muhammad \\ Jamil Khan ${ }^{1}$, Abida Saleem ${ }^{1}$ and Zarina Bibi ${ }^{1}$ \\ 1. Department of Soil Science, Gomal University, Dera Ismail Khan-Pakistan \\ 2. Agricultural Research Station, Serai Naurang, Bannu-Pakistan \\ *Corresponding author's email: qudratbaloch@yahoo.com \\ Citation \\ Zaheer Ahmad, Qudrat Ullah Khan, Abdul Qadoos, Muhammad Jamil Khan, Abida Saleem and Zarina Bibi. Humic \\ acid, an effective amendment used for amelioration of Phosphatic fertilizer and enhancing maize yield. Pure and \\ Applied Biology. Vol. 9, Issue 1, pp750-759. http://dx.doi.org/10.19045/bspab.2020.90081
}

\begin{tabular}{llll}
\hline \hline Received: 17/09/2019 & Revised: 01/12/2019 & Accepted: 07/12/2019 & Online First: 23/12/2019 \\
\hline
\end{tabular}

\section{Abstract}

Humic acid (HA) is an important concentrated organic material which has been found effective in amelioration of nutrients and their availability to plants. To study the effect of HA integrated with phosphatic fertilizer a field trial was carried out on maize crop. In the field experiment randomized complete block design in a split plot pattern was used. The main plots were assigned to humic acid and without humic acid, while the sub - plots were allocated to P fertilizer levels i.e. 40, 80, 120, 160 and $200 \mathrm{~kg} \mathrm{P}_{2} \mathrm{O}_{5} \mathrm{ha}^{-1}$. Results recorded after the harvest of crop showed HA applied in integration with phosphatic fertilizer was effective in improving the properties of soil. Soil $\mathrm{pH}$ was significantly decreased, while organic matter content, soil nitrogen and phosphorus significantly enhanced. Also the agronomic traits studied viz. plant height $(187.69 \mathrm{~cm})$, leaf area $\left(334.57 \mathrm{~cm}^{2}\right)$, leaf area index $\left(16549.8 \mathrm{~cm}^{2}\right)$, grains ear-1 $(310.33)$, biological yield $\left(16471.7 \mathrm{~kg} \mathrm{ha}^{-1}\right), 100$ grain weight $(24.44 \mathrm{~g})$, grain yield $\left(3085.99 \mathrm{~kg} \mathrm{ha}^{-1}\right)$ were found significantly higher in the plots receiving humic acid along with phosphorus @ $120 \mathrm{~kg} \mathrm{P}_{2} \mathrm{O}_{5} \mathrm{ha}^{-1}$. The benefit cost ratio (BCR) was found higher (2.90) for the plots receiving HA along with phosphatic fertilizer @ $120 \mathrm{~kg} \mathrm{ha}^{-1}$ as compared with the rest of the treatments. It may be concluded that humic acid is an important amendment used from improving soil properties. Also its application along with applied with phosphatic fertilizer @ $120 \mathrm{~kg} \mathrm{ha}^{-1}$ was economical and also gave higher maize growth and yield.

Keywords: Economics; Humic acid; Maize; Phosphatic fertilizer; Yield

Introduction

Humic acid is the ultimate breakdown of the organic material. It is formed by the process of humification by the involvement of microbes in soil. Humic acid is an organically complex molecule derived from the organic matter. It is an important organic source which improves the soil physical condition and also provides the nutrients essential for plant growth [1]. Amongst the plant macro nutrients Phosphorus $(\mathrm{P})$ is ranked second after nitrogen. The availability of $\mathrm{P}$ to plants has been inconsistent due to its dynamic behavior in soil and its active adsorption on soil particles. Phosphate in soil solution is readily available to plants [2], but as it adsorbed its availability reduces. The phenomenon of adsorption is mostly confined to soil $\mathrm{pH}$, Organic matter, lime content and clayey texture.

Soils in Pakistan have less available P [3]. The low $\mathrm{P}$ content may be attributed to 
alkaline $\mathrm{pH}>7.0$, higher $\mathrm{CaCO}_{3}$ content (> $3.0 \%)$ and low organic matter content $(>1 \%)$ which resulted in less availability of $\mathrm{P}$ to plants [4]. In alkaline and calcareous soil, $P$ is precipitated with different ions as $\mathrm{Al}-$ phosphate, $\mathrm{Ca}$ - phosphate and becomes unavailable for plants $[5,6]$. Several strategies are being used to alleviate this problem one of which is the use of inorganic $P$ fertilizers (usually SSP or TSP). High cost and water quality problems arising from inorganic fertilizers, use of inorganic fertilizers has gain popularity. Use of organic substance to combat $\mathrm{P}$ deficiency is a sustainable approach. Organic substances as humic acid added to alkaline soil may enhance its availability. Humic acid not only influence the soil physicochemical characteristics and microbial activity but also result in nutrient availability to plants and effect growth of plant by influencing the root growth [7]. Pakistani soils are organic matter deficient so use of humic acid may be very beneficial [8]. Use of Humic acid may decrease the application of inorganic fertilizers as it is the rich source of plant nutrients. Humic acid contains carboxylate and phenolate groups which has the ability to form complexes with different ions and nutrients and act as chelate. The bioavailability of nutrients and ions may be regulated by the formation of these complexes [9].

In the current study Maize (Zea mays L.) has been used as test crop. Maize ranks $4^{\text {th }}$ amongst the major cereal crops grown in Pakistan. It is used as a staple food in most of the area of Khyber Pakhtunkhaw province and utilizes for poultry and animals feed [10].
The baking products, corn, starch, dextrose, corn syrup etc. are prepared from maize [11]. Keeping in view the importance of maize crop and use of humic acid with inorganic fertilizer the current study was designed with objective to determine the effect of integrated use of humic acid with posphatic fertilizer on agronomic parameters of maize and soil properrties.

\section{Materials and methods}

To evaluate the significance of humic acid in amelioration of phosphatic fertilizer a field trial was carried out at agriculture research station Serai Naurang, Bannu, (GPS coordinate of $32^{\circ} 49^{\prime} 32^{\prime \prime} \mathrm{N} \quad 70^{\circ} 466^{\prime} 55^{\prime \prime} \mathrm{E}$ ) during summer 2017. The field trial was laid in Randomized Complete Block design with a pattern split plot. The humic and non humic plots were placed in the main plots while the phosphatic fertilizer dosage were kept in the sub - plots. Spring maize variety "Azam" was sown used @ $30 \mathrm{~kg} \mathrm{ha}^{-1}$. The organic component (humic acid 10\% w/w + $\mathrm{K}_{2} \mathrm{O} 7 \%$ w/w) was purchased from the local market and applied @ $7.5 \mathrm{~kg} \mathrm{ha}^{-1}$ to the respective plots. While, Diammonium phosphate (DAP) as source of $\mathrm{P}$ fertilizer was applied @ 40, 80, 120, 160 and 200 kg $\mathrm{P}_{2} \mathrm{O}_{5}$ $\mathrm{ha}^{-1}$. The primary nutrients NK were applied equally@120: $60 \mathrm{~kg} \mathrm{ha}^{-1}$ to all the plots. All the management practices including weeding, hoeing and irrigations were uniformly carried out in the experiment.

Different growth and yield parameters of maize crop were studied during the course of experiment. Leaf area $\left(\mathrm{cm}^{2}\right)$ [12] and Leaf area index was determined using the formulas given below:

Leaf Area $=$ Leaf Length $\times$ Width $\times 0.75$

Leaf area Index $=$ Leaf area $\times$ No. of leaves per plant $\times$ Plants $^{-2}$

Soil samples analyzed for Physico-chemical characteristics prior to the sowing of maize are presented in (Table 1). Soil properties including soil $\mathrm{pH}$ [13], Soil organic matter
(\%) [14], Nitrogen [13], Phosphorus were also determined after harvesting of crop [15]. To compare the means statistical analysis were carried out using statistical package 
statistics 8.1. Least significance difference (LSD) used for comparing the means by procedure given by [16]. Economics of the treatment will be determined by calculating the benefit cost ratio (BCR).

Table. 1 Physico - chemical characteristics of the soil at sowing of Maize crop

\begin{tabular}{|c|c|}
\hline Soil property & Value \\
\hline Soil texture & Clay loam \\
\hline $\mathrm{pH}$ & 7.93 \\
\hline $\mathrm{ECe}\left(\mu \mathrm{S} \mathrm{cm}^{-1}\right)$ & 432 \\
\hline Bulk Density $\left(\mathrm{g} \mathrm{cm}^{-3}\right)$ & 1.27 \\
\hline $\mathrm{CaCO}_{3}(\%)$ & 8.45 \\
\hline Total Nitrogen $(\%)$ & 0.027 \\
\hline Extractable phosphorus $\left(\mathrm{mg} \mathrm{kg}^{-1}\right)$ & 5.46 \\
\hline Organic matter $(\%)$ & 0.43 \\
\hline
\end{tabular}

\section{Results and discussion}

\section{Effect of Humic acid and phosphatic fertilizers on soil properties}

\section{Soil pH}

Soil $\mathrm{pH}$ is an important soil property which influences the nutrients availability, microbial activity etc. The data regarding the soil $\mathrm{pH}$ recorded by the application of the treatments showed significant reduction as compared to the control. (Table 2). Highest reduction in soil $\mathrm{pH}$ was observed i.e.6.63 in the plots treated with phosphatic fertilizer@ $200 \mathrm{~kg} \mathrm{P}_{2} \mathrm{O}_{5} \mathrm{ha}^{-1}$ combination with HA (Table 2). It clearly showed that phosphatic fertilizer was effective in reducing soil $\mathrm{pH}$ and those treatments receiving HA showed more reduction in $\mathrm{pH}$. Humic acid application influences on soil chemical properties. and also concluded that soil $\mathrm{pH}$ was enhanced by increasing the application of HA. The organic compounds which includes fulvic acid and humic acid also having the ability of complex cations [17]. Humic acid was also known of having high CEC and surface area as compared to soil collides [18].

Soil organic matter $(\%)$
The application of treatments of humic acid and phosphatic fertilizer showed significant influence on the organic matter of soil (Table $2)$. The highest organic matter was recorded $1.18 \%$ in the plot receiving humic acid and phosphorus@120 kg ha ${ }^{-1}$. The minimum organic matter value was recorded in control and was $0.32 \%$. Humate applied to soil significantly increased percent organic matter and root mass in creeping bent grass turf. Humic acid application to the soil increase soil \% O.M and result in better crop growth. It also improves the soil properties as increase cation exchange capacity, chelating of elements, and increase availability of nutrients to plants. Humic acid stimulates the activity of microbial biomass and can be used as effective organic fertilizer [19]. Organic matter influences the capacity of soil and soil microbes and also increases the activity of enzymes [20].

Total nitrogen (\%)

Humic acid applied in integration with the phosphatic fertilizer has shown significant effect on the soil nitrogen (Table 2). The maximum nitrogen of $0.10 \%$ was found in $\mathrm{T}_{4}$ plot receiving Phosphatic fertilizer @ 160 kg $\mathrm{ha}^{-1}$ along with HA followed by the $\mathrm{T}_{3}$ plot 
receiving Phosphatic fertilizer @ $120 \mathrm{~kg} \mathrm{ha}^{-1}$ along with HA where $0.08 \%$. nitrogen was found. The minimum nitrogen of 0.01 was found in control without HA. Our findings were in accordance with the results of Saif eldeen [21] and Selim et al. [22] who found that application of HA with primary macronutrients can enhance N,P and $\mathrm{K}$ concentrations. They supposed that the taking of $\mathrm{N}$ by the plants is due to the best efficiency of $\mathrm{N}$ when applied in combination of HA. It decreased the nitrification process and thus results in the slow release and availability of $\mathrm{N}$. Phosphorus helps in the conversion of other nutrients to usable form for plants.

\section{Soil phosphorus ( $\left.\mathrm{mg} \mathrm{kg}^{-1}\right)$}

The data pertaining to determination of soil Phosphorus was significantly influenced by the application of treatments of Humic acid and phosphatic fertilizers in combination and as sole over control (Table 2). The maximum phosphorus of $9.75 \mathrm{mg} \mathrm{kg}^{-1}$ was found in $\mathrm{T}_{3}$ plot receiving Phosphatic fertilizer @ $120 \mathrm{~kg}$ $\mathrm{ha}^{-1}$ amended with HA. It was statistically at par to the treatments $\mathrm{T}_{2 \mathrm{~S}}$ amended with HA and $\mathrm{T}_{2}, \mathrm{~T}_{3}$ and $\mathrm{T}_{4}$ without $\mathrm{HA}$. The minimum phosphorus of $5.54 \mathrm{mg} \mathrm{kg}^{-1}$ was found in control without HA amendment. Our results were similar to the findings of different workers who studied that when coal of humic substances were applied to soil @2 kg ha ${ }^{-1}$ resulted in more phosphorus availability by conductivity in soil and it also suppressed the phosphorus fixation by chelating and by mineralization of microbes [23]. The availability of phosphorus can be increased and fixation of $\mathrm{P}$ can be reduced by the HA applications to soil [24]. The plants avail more $\mathrm{P}$ by the addition of humic acid to soil of alkalinity nature. It helps in decreasing $\mathrm{P}$ fixation and also play a role in providing phosphorus in solution form to plants. The yield of cereal crop and the use of phosphorus can also enhanced by the presence of humic acid [7].
Growth parameters of Maize as affected by the application of Humic acid and Phosphatic fertilizers

\section{Plant height}

Application of $\mathrm{P}$ fertilizer amended with HA increased the maize plant heights. The taller plants of $187.693 \mathrm{~cm}$ were recorded in treatment where phosphatic fertilizer @ 120 $\mathrm{kg} \mathrm{ha}^{-1}$ along with HA was used (Table 3). The treatments of all phosphatic levels along with HA were statistically at par. The shortest stature plants of size $169.51 \mathrm{~cm}$ were found in control $\left(\mathrm{T}_{0}\right)$ without HA. Similar results have been found by other researchers who have observed increase in plant height by applying humic acid as it improved the physical condition of the soil and nutrients availability to plant [23]. Also others have reported that plant height increases with the use of organic manures [25]. Phosphorus has been found as a nutrient which improves the root growth and has overall effect on plant growth. It promotes plant height by high $\mathrm{P}$ level and considered better for elongation of roots and nutrients availability in root zone, also enhances nutrient uptake by plants [26]. Leaf area $\left(\mathrm{cm}^{2}\right)$

Leaf area of plant influence the physiological function of crop. In the current study the maximum leaf area of $334.57 \mathrm{~cm}^{2}$ was found in phosphatic fertilizer plot @ $120 \mathrm{~kg} \mathrm{ha}^{-1}$ (T3) in combination with HA (Table 3 ). The smallest leaf area was recorded $244.31 \mathrm{~cm}^{2}$ in $\mathrm{T}_{0}$ without $\mathrm{HA}$. The enhanced effect of organic manure on leaf area of plants has been reported by Muhammad and Khattak [25]. Leaf area of sweet potato has been reported to be enhanced by the use of Phosphatic fertilizer [27].

\section{Leaf area index $\left(\mathrm{cm}^{2}\right)$}

The data regarding leaf area index showed the highest leaf area index of $16549.8 \mathrm{~cm}^{2}$ found in plots receiving Humic acid along with the phosphatic fertilizer @ $120 \mathrm{~kg} \mathrm{ha}^{-1}$. It was statistically similar to the treatments $\mathrm{T}_{4}$ with HA and $\mathrm{T}_{3}$ and $\mathrm{T}_{4}$ without HA (Table 
3). The minimum leaf area index of plants $11443.9 \mathrm{~cm}^{2}$ were found in control without HA. The plants of leguminous family showed remarkable vegetative growth by applying foliar spray of humic acid and enhanced the production of food from light and had greater leaf area index [28]. Also in cowpea the leaf area index was found significantly influenced by the influence of humic acid [29].

Yield parameters of Maize as affected by the application of Humic acid and Phosphatic fertilizers

Number of Grains ear ${ }^{-1}$

Number of grains ear ${ }^{-1}$ significantly increased by the application of phosphatic fertilizer amended with HA. Humic acid applied with phosphate@120 kg ha ${ }^{-1}$ gave maximum value of 310.33 . However, plots of $\mathrm{T}_{2}$ and $\mathrm{T}_{4}$ amended with HA were statistically at par.. The lowest numbers of grains ear ${ }^{-1}$ were recorded in control without HA (Table 4). The application of phosphorus enhances the number of ear in maize plants. It is concluded that if the number of ears in a plant decreased then alternatively the grain yield will be declined. But increase in phosphorus application above $120 \mathrm{~kg} \mathrm{ha}^{-1}$ did not have significant effect on the number of grains $\mathrm{cob}^{-1}$ of maize which is clear from those plots which received P@160 kg ha ${ }^{-1}$ that lead to less number of grains $\mathrm{cob}^{-1}$. Phosphatic fertilizer significantly increased the grains of maize [30]. Similarly the number of grains $\mathrm{cob}^{-1}$ was influenced significantly by applying NP doses [31].

Biological yield (kg ha-1)

Application of P fertilizer @ $120 \mathrm{~kg} \mathrm{p} \mathrm{ha}^{-1}$ along with HA gave higher yield of 16471.7 $\mathrm{kg} \mathrm{ha} \mathrm{h}^{-1}$ and was found to be a good combination (Table 4). The lowest biological yield of $7902.53 \mathrm{~kg} \mathrm{ha}^{-1}$ was observed in $\mathrm{T}_{0}$ without HA. Humic acid could influence root growth and morphology by releasing organic acid that may increase nutrient uptake and result in improved growth and yield of crops
[32]. Humic acid increases the growth parameters of maize fodder [33]. Application of phosphatic fertilizer has significant effect on wheat crop [34]. Highest biological yields is recorded in plots receiving Phosphate [35].

\section{0 grain weight $(\mathrm{g})$}

The weight of 1000 grain (g) was increased with the application of HA and phosphatic fertilizer. The maximum value of $24.44 \mathrm{~g}$ was found in a plot treated with $\mathrm{P}_{2} \mathrm{O}_{5} @ 120 \mathrm{~kg}$ $\mathrm{ha}^{-1}$ along with HA. It was statistically similar with HA plots $\left(\mathrm{T}_{2}\right)$ and without HA $\mathrm{T}_{2}, \mathrm{~T}_{3}$ and $\mathrm{T}_{4}$. The least 100 grain weight of $19.73 \mathrm{~g}$ was found in control without HA (Table 4). The findings of Alam et al. [35] also reveals that the maximum weight of thousand grains were in those plots which received $120 \mathrm{~kg} \mathrm{~N} \mathrm{ha}^{-1}$.

\section{Grain yield ( $\left.\mathrm{kg} \mathrm{ha}^{-1}\right)$}

Combined application of $\mathrm{HA}$ and phosphate fertilizer increased the Grain yield $\left(\mathrm{kg} \mathrm{ha}^{-1}\right)$ of maize crop. The grain yield was recorded maximum $3085.99 \mathrm{~kg} \mathrm{ha}^{-1}$ in the treatment where HA was integrated with phosphorus @ $120 \mathrm{~kg} \mathrm{ha}^{-1}$. It was statistically at par with $\mathrm{T}_{2}$ with $\mathrm{HA}$ and $\mathrm{T}_{3}$ without HA. The lowest yield of $1730.76 \mathrm{~kg} \mathrm{ha}^{-1}$ was determined in control without HA (Table 4). The application of phosphatic fertilizer showed significantly increase in the marketable yield [36]. Humic acid can enhance the yield of grains up to $21-25 \%$ with the accumulation of nutrients [8].

\section{Economics of treatments}

The economics calculated after the experiment and compared between the humic acid and non humic acid along with Phosphatic fertilizer plots showed the highest BCR of 2.90 in the treatment receiving Phosphatic fertilizer @120 kg ha ${ }^{-1}$ with humic acid. In the non - humic plots the BCR of 2.66 in the plot receiving $40 \mathrm{~kg} \mathrm{ha}^{-}$ ${ }^{1}$ was found. The lowest BCR of 1.60 and 1.40 was found in T5 with and without HA respectively (Table 5). 
Table 2. Soil Physico-chemical analysis as influenced by the application of humic acid and phosphatic fertilizer

\begin{tabular}{|c|c|c|c|c|c|c|c|c|}
\hline \multirow{2}{*}{ Treatments } & \multicolumn{2}{|c|}{ Soil pH } & \multicolumn{2}{c|}{$\begin{array}{c}\text { Soil organic matter } \\
(\%)\end{array}$} & \multicolumn{2}{c|}{$\begin{array}{c}\text { Soil nitrogen } \\
(\%)\end{array}$} & $\begin{array}{c}\text { Soil phosphorus } \\
\left(\mathbf{m g} \mathbf{~ k g}^{-1}\right)\end{array}$ \\
\cline { 2 - 9 } & HA & Without HA & HA & Without HA & HA & Without HA & HA & Without HA \\
\hline $\mathrm{T}_{0}(\mathrm{control})$ & $7.76 \mathrm{ab}$ & $8 \mathrm{a}$ & $0.54 \mathrm{de}$ & $0.32 \mathrm{e}$ & $0.02 \mathrm{ef}$ & $0.01 \mathrm{f}$ & $6.59 \mathrm{~d}$ & $5.54 \mathrm{e}$ \\
\hline $\mathrm{T}_{1}\left(40 \mathrm{~kg} \mathrm{P}_{2} \mathrm{O}_{5} \mathrm{ha}^{-1}\right)$ & $7.5 \mathrm{ab}$ & $8.06 \mathrm{a}$ & $0.87 \mathrm{~d}$ & $0.43 \mathrm{de}$ & $0.03 \mathrm{def}$ & $0.02 \mathrm{def}$ & $8.05 \mathrm{bc}$ & $6.44 \mathrm{~d}$ \\
\hline $\mathrm{T}_{2}\left(80 \mathrm{~kg} \mathrm{P}_{2} \mathrm{O}_{5} \mathrm{ha}^{-1}\right)$ & $7.34 \mathrm{ab}$ & $7.80 \mathrm{ab}$ & $1.02 \mathrm{~b}$ & $0.71 \mathrm{~cd}$ & $0.05 \mathrm{bcd}$ & $0.03 \mathrm{def}$ & $8.45 \mathrm{~b}$ & $7.59 \mathrm{c}$ \\
\hline $\mathrm{T}_{3}\left(120 \mathrm{~kg} \mathrm{P}_{2} \mathrm{O}_{5} \mathrm{ha}^{-1}\right)$ & $7.17 \mathrm{bc}$ & $7.63 \mathrm{ab}$ & $1.18 \mathrm{a}$ & $0.75 \mathrm{~b}$ & $0.08 \mathrm{~b}$ & $0.04 \mathrm{cde}$ & $9.75 \mathrm{a}$ & $9.3 \mathrm{~b}$ \\
\hline $\mathrm{T}_{4}\left(160 \mathrm{~kg} \mathrm{P}_{2} \mathrm{O}_{5} \mathrm{ha}^{-1}\right)$ & $7.43 \mathrm{ab}$ & $7.57 \mathrm{ab}$ & $1.04 \mathrm{bc}$ & $0.62 \mathrm{~cd}$ & $0.10 \mathrm{a}$ & $0.06 \mathrm{bc}$ & $7.90 \mathrm{bc}$ & $7.60 \mathrm{c}$ \\
\hline $\mathrm{T}_{5}\left(200 \mathrm{~kg} \mathrm{P}_{2} \mathrm{O}_{5} \mathrm{ha}^{-1}\right)$ & $6.63 \mathrm{c}$ & $7.8 \mathrm{ab}$ & $0.77 \mathrm{de}$ & $0.57 \mathrm{de}$ & $0.034 \mathrm{def}$ & $0.03 \mathrm{def}$ & $8.84 \mathrm{~d}$ & $7.44 \mathrm{~d}$ \\
\hline $\mathrm{LSD}$ & \multicolumn{2}{|c|}{0.7971} & \multicolumn{2}{|c|}{0.1837} & \multicolumn{2}{c|}{0.0314} & & 0.6163 \\
\hline
\end{tabular}

Means followed by similar letter in a column are significant at 5\% level of significance

Table 3. Growth parameters of maize plants as influenced by various $P$ levels with and without humic acid

\begin{tabular}{|c|c|c|c|c|c|c|}
\hline \multirow{2}{*}{ Treatments } & \multicolumn{2}{|c|}{ Plant height (cm) } & \multicolumn{2}{|c|}{ Leaf area $\left(\mathrm{cm}^{2}\right)$} & \multicolumn{2}{|c|}{ Leaf area index $\left(\mathrm{cm}^{2}\right)$} \\
\hline & HA & Without HA & HA & Without HA & HA & Without HA \\
\hline $\mathrm{T}_{0}$ (Control) & $180.217 \mathrm{bcd}$ & $169.51 \mathrm{e}$ & $292.217 \mathrm{~cd}$ & $244.31 \mathrm{~g}$ & $12251.8 \mathrm{~cd}$ & $11443.9 \mathrm{e}$ \\
\hline $\mathrm{T}_{1}\left(40 \mathrm{~kg} \mathrm{P}_{2} \mathrm{O}_{5} \mathrm{ha}^{-1}\right)$ & $183.6 \mathrm{abc}$ & $176.59 \mathrm{~d}$ & $312.06 \mathrm{~b}$ & $253.872 \mathrm{f}$ & $13460.3 \mathrm{c}$ & $11998.8 \mathrm{cde}$ \\
\hline $\mathrm{T}_{2}\left(80 \mathrm{~kg} \mathrm{P}_{2} \mathrm{O}_{5} \mathrm{ha}^{-1}\right)$ & $185.367 \mathrm{a}$ & $183.853 \mathrm{ab}$ & $318.102 b$ & $285.441 d$ & 14471.1b & $12630.6 \mathrm{~cd}$ \\
\hline $\mathrm{T}_{3}\left(120 \mathrm{~kg} \mathrm{P}_{2} \mathrm{O}_{5} \mathrm{ha}^{-1}\right)$ & $187.693 \mathrm{a}$ & $184.393 \mathrm{ab}$ & $334.572 \mathrm{a}$ & $298.06 \mathrm{c}$ & $16549.8 \mathrm{a}$ & $14811.4 \mathrm{ab}$ \\
\hline $\mathrm{T}_{4}\left(160 \mathrm{~kg} \mathrm{P}_{2} \mathrm{O}_{5} \mathrm{ha}^{-1}\right)$ & $185.993 \mathrm{a}$ & $178.697 \mathrm{~cd}$ & $298.76 c$ & $287.418 \mathrm{~d}$ & $14958.9 \mathrm{ab}$ & 13985.2abc \\
\hline $\mathrm{T}_{5}\left(200 \mathrm{~kg} \mathrm{P}_{2} \mathrm{O}_{5} \mathrm{ha}^{-1}\right)$ & $184.82 \mathrm{ab}$ & $178.217 \mathrm{~d}$ & $267.806 \mathrm{e}$ & $249.457 \mathrm{fg}$ & $13123 \mathrm{cde}$ & $12261.6 \mathrm{~cd}$ \\
\hline LSD & \multicolumn{2}{|c|}{4.9445} & \multicolumn{2}{|c|}{10.239} & \multicolumn{2}{|c|}{936.45} \\
\hline
\end{tabular}

Means followed by similar letter in a column are significant at $5 \%$ level of significance 
Table 4. Yield parameters of maize plants as influenced by various $P$ levels with and without humic acid

\begin{tabular}{|c|c|c|c|c|c|c|c|c|}
\hline \multirow{2}{*}{ Treatments } & \multicolumn{2}{|c|}{ Grains ear $^{-1}$} & \multicolumn{2}{|c|}{ Biological yield $\left(\mathrm{kg} \mathrm{ha}^{-1}\right)$} & \multicolumn{2}{|c|}{100 grains weight $(\mathrm{g})$} & \multicolumn{2}{|c|}{ Grains yield $\left(\mathrm{kg} \mathrm{ha}^{-1}\right)$} \\
\hline & HA & Without HA & HA & Without HA & HA & Without HA & HA & Without HA \\
\hline $\mathrm{T}_{0}($ Control $)$ & $234.66 \mathrm{j}$ & $210 \mathrm{k}$ & 9205.04def & $7902.53 \mathrm{f}$ & $22.13 b c$ & $19.73 d$ & $1945.10 \mathrm{~g}$ & $1730.76 \mathrm{~h}$ \\
\hline $\mathrm{T}_{1}\left(40 \mathrm{~kg} \mathrm{P}_{2} \mathrm{O}_{5} \mathrm{ha}^{-1}\right)$ & $270.66 f$ & $248 \mathrm{~h}$ & 11808.07abcdef & 9846.97cdef & $22.32 \mathrm{bc}$ & $21.66 \mathrm{~cd}$ & $2312.22 \mathrm{~cd}$ & $2085.12 \mathrm{gh}$ \\
\hline $\mathrm{T}_{2}\left(80 \mathrm{~kg} \mathrm{P}_{2} \mathrm{O}_{5} \mathrm{ha}^{-1}\right)$ & $294.33 b$ & $282.33 d$ & $14595.95 \mathrm{abc}$ & 11747.4abcdef & $23.98 \mathrm{ab}$ & $22.77 \mathrm{abc}$ & $2488.86 b$ & $2279.9 \mathrm{de}$ \\
\hline $\mathrm{T}_{3}\left(120 \mathrm{~kg} \mathrm{P}_{2} \mathrm{O}_{5} \mathrm{ha}^{-1}\right)$ & $310.33 a$ & $289.33 c$ & $16471.71 \mathrm{a}$ & $14697.1 \mathrm{ab}$ & $24.44 \mathrm{a}$ & $23.48 \mathrm{abc}$ & $3085.99 a$ & $2691.13 b c$ \\
\hline $\mathrm{T}_{4}\left(160 \mathrm{~kg} \mathrm{P}_{2} \mathrm{O}_{5} \mathrm{ha}^{-1}\right)$ & $292.66 \mathrm{c}$ & $265 \mathrm{~g}$ & 13533.33abcd & 12979.9abcde & $22.13 b c$ & $22.56 \mathrm{abc}$ & $2874.09 \mathrm{~cd}$ & 2441.9de \\
\hline $\mathrm{T}_{5}\left(200 \mathrm{~kg} \mathrm{P}_{2} \mathrm{O}_{5} \mathrm{ha}^{-1}\right)$ & $276.33 \mathrm{e}$ & $243.33 \mathrm{i}$ & $10484.84 \mathrm{bcdef}$ & $8328.66 \mathrm{ef}$ & $21.85 \mathrm{c}$ & $22.25 b c$ & $2545.41 \mathrm{ef}$ & $2254.46 f g$ \\
\hline LSD & \multicolumn{2}{|c|}{3.4215} & \multicolumn{2}{|c|}{5153.2} & \multicolumn{2}{|c|}{1.9044} & \multicolumn{2}{|c|}{103.24} \\
\hline
\end{tabular}

Means followed by similar letter in a column are significant at $5 \%$ level of significance

Table 5. Economics of the treatments as affected by the application of humic acid and Phosphatic fertilizer

\begin{tabular}{|c|c|c|c|c|c|c|c|c|}
\hline \multirow[b]{2}{*}{ Treatments } & \multicolumn{4}{|c|}{ Humic Acid } & \multicolumn{4}{|c|}{ Without Humic Acid } \\
\hline & $\begin{array}{c}\text { Total Income } \\
\text { (Rs.) }\end{array}$ & $\begin{array}{l}\text { Total Cost } \\
\text { (Rs.) }\end{array}$ & $\begin{array}{l}\text { Net Return } \\
\text { (Rs.) }\end{array}$ & BCR & $\begin{array}{c}\text { Total } \\
\text { Income (Rs.) }\end{array}$ & $\begin{array}{l}\text { Total Cost } \\
\text { (Rs.) }\end{array}$ & $\begin{array}{l}\text { Net Return } \\
\text { (Rs.) }\end{array}$ & BCR \\
\hline $\mathrm{T}_{\mathrm{o}}($ Control $)$ & 136157 & 35985 & 100172 & 2.78 & 121153.2 & 33360 & 87793.2 & 2.63 \\
\hline $\mathrm{T}_{1}\left(40 \mathrm{~kg} \mathrm{P}_{2} \mathrm{O}_{5} \mathrm{ha}^{-1}\right)$ & 161855.4 & 42450.26 & 119405.14 & 2.81 & 145958.4 & 39825.26 & 106133.14 & 2.66 \\
\hline $\mathrm{T}_{2}\left(80 \mathrm{~kg} \mathrm{P}_{2} \mathrm{O}_{5} \mathrm{ha}^{-1}\right)$ & 174220.2 & 48916.35 & 125303.85 & 2.56 & 159593 & 46291.35 & 113301.65 & 2.44 \\
\hline $\mathrm{T}_{3}\left(120 \mathrm{~kg} \mathrm{P}_{2} \mathrm{O}_{5} \mathrm{ha}^{-1}\right)$ & 216019.3 & 55381.97 & 160637.33 & 2.90 & 188379.1 & 52756.97 & 135622.13 & 2.57 \\
\hline $\mathrm{T}_{4}\left(160 \mathrm{~kg} \mathrm{P}_{2} \mathrm{O}_{5} \mathrm{ha}^{-1}\right)$ & 201186.3 & 61849.21 & 139337.09 & 2.25 & 170933 & 59224.21 & 111708.79 & 1.88 \\
\hline $\mathrm{T}_{5}\left(200 \mathrm{~kg} \mathrm{P}_{2} \mathrm{O}_{5} \mathrm{ha}^{-1}\right)$ & 178178.7 & 68314.44 & 109864.26 & 1.60 & 157812.2 & 65689.44 & 92122.76 & 1.40 \\
\hline
\end{tabular}




\section{Conclusion}

The study reached the conclusion that plant height, 100 grains weight, ear length, leaf area, leaf area index, biological yield, number of grains ear ${ }^{-1}$, number of ears plant ${ }^{-1}$ and grain yield were significantly increased by humic acid application as compared to those plots which were without humic acid. Also it has been found that the physic - chemical characteristics studied during the experiment showed significant effect on total nitrogen, organic matter, $\mathrm{pH}$ and extractable phosphorus. Based on these finding it may be suggested that the application of phosphatic fertilizer @ $120 \mathrm{~kg} \mathrm{ha}^{-1}$ in combination with humic acid significantly influence the growth and yield parameter of maize crop, physico chemical characteristics of soil and economics of the farmer as compared to the other phosphatic fertilizer treatments with and with humic acid treatments.

\section{Authors' contributions}

Conceived and designed the experiments: $\mathrm{Z}$ Ahmad \& QU Khan, Performed the experiments: Z Ahmad \& A Qadoos, Analyzed the data: QU Khan \& A Saleem, Contributed materials/ analysis/ tools: M Jamil Khan \& Z Bibi, Wrote the paper: QU Khan \& Z Ahmad.

\section{References}

1. Chen Y \& Aviad T (1990). Effects of humic substances on plant growth. In: Humic substances in soil and crop sciences: selected readings (MacCarthy P, Clapp C, Malcolm RL, Bloom PR, Eds). Is Soc Agron, Madison, WI, USA. pp 161-186.

2. Ahmad N \& Rashid M (2003). Fertilizer and their Uses in Pakistan. NFDC. Planning and Development Div. Islamabad. pp 17.

3. Rashid A, Awan ZI \& Ryan J (2005). Diagnosing phosphorus deficiency in spring wheat by plant analysis: Proposed critical concentration ranges. Commun Soil Sci Plant Anal 36: 609-622.
4. Yaseen M, Gill MA, Siddique M, Ahmed Z, Mahmood T \& Hamud-urRehman (1998). Phosphorus deficiency stress tolerance and phosphorus utilization efficiency in wheat genotypes. In: Proceeding of Symposium on plant nutrition management for sustainable agric. growth. Govt. of Pakistan, Planning and Development Division NFDC, Islamabad.

5. Reddy KR, Kadlec, RH, Flaig E \& Gale, PM (1999). Phosphorus retention in streams and wetlands: A review. Critical Rev Env Sci Tech 29(1): 83-146.

6. Slaton NA, Wilson Jr, CE Norman, RJ Ntamatungiro, S \& Frizzell DL (2002). Rice Response to Phosphorus Fertilizer Application Rate and Timing on Alkaline Soils in Arkansas, Agron J 94: 1393-1399.

7. Puglisi E, Pascazio S, Suciu N, Cattani I, Fait G, Spaccini R, Crecchio C, Piccolo A, Trevisan M (2013) Rhizosphere microbial diversity as influenced by humic substance amendments and chemical composition of rhizodeposits. $J$ Geochem Explor 129: 82-94.

8. Sharif M, Khattak, RA \& Sarir MS (2002). Effect of different levels of lignitic coal derived HA on growth of maize plants. Commun. Soil Sci Plant Anal 19-20.

9. Verlinden G, Pycke B, Mertens J, Debersaques F, Verheyen K, Baert G, Bries J \& Haesaert G (2009). Application of humic substances results in consistent increases in crop yield and nutrient uptake. J Plant Nut 32: $1407-$ 1426.

10. Amanullah, Asif M, Malhi SS \& Khattak RA (2009). Effects of phosphatic fertilizer source and plant density on growth and yield of maize in northwestern Pak J Plant Nut 32(12): 2080-2093. 
11. Khaliq T, Mahmood T, Kamal J \& Masood A (2004). Effectiveness of farmyard manure, poultry manure and nitrogen for corn (Zea mays L.) productivity. Int J Agric Bio 2: 260-263.

12. Dwyer LM \& DW Stewart (1986). Leaf area development in field-grown maize. Agron J 78: 334-343.

13. Ryan J, Estefan G \& Rashid A (2001). Soil and Plant Analysis Laboratory Manual (2nd Ed.). Jointly published by the International Center for Agricultural Research in the Dry Areas (ICARDA) and the National Agricultural Research Center (NARC). Available from ICARDA, Aleppo, Syria. pp. 172.

14. Nelson DW \& Sommer LE (1982). Total carbon, organic carbon, and organic matter. p. 539-579. In Page, AL (ed.) Methods of Soil Analysis. 2nd Ed. ASA Monogr. Amer Soc Agron Madison, WI. 9(2).

15. Watanabe FS \& Olsen SR (1965). Test of an Ascorbic Acid Method for Determining Phosphorus in Water and $\mathrm{NaHCO} 3$ Extracts from the Soil. Soil Sci Soc America J 29: 677-678.

16. Steel RGD, Torrie JH \& Dickey DA (1997). Principles and Procedures of Statistics. A biometrical approach. $3^{\text {rd }}$. (Ed). McGraw Hill Companies, Inc. New York, USA.

17. Harper SM, Kerven, GL \& Edwards DG (2000). Characterizations of fulvic and humic acids from leaves of Eucalyptus camaldulensis and from decomposed hay. Soil Bio Biochem 32: 1331-1336.

18. Bohn, HL, McNeal BL, O’Connor \& George A (2001). Soil Chemistry. A Wiley Inter-science Publication. John Wiley and Sons, New York.

19. Sarwar M, Ehsan AM. \& Hyder SI (2012). Effect of humic acid and phosphorus on yield, nutrient availability in soil and uptake by peas. Prime $J$ Physical Sci 1(5): 53-57.
20. Liang, YC, Yang YF, Yang CG, Shen QQ, Zhou JM \& Yang LZ (2003). Soil enzymatic activity and growth of rice and barley as influenced by organic matter in an anthropogenic soil. Geoderma 115: 149-160.

21. Saif el-deen, UM, Ezzat AS \& El-morsy HA (2011). Effect of phosphorus fertilizer rates and application methods of humic acid on productivity and quality of sweet potato. Veg. Res. Dep., hort. Res. Inst., agric. Res. Center, giza, egypt. J Plant Production, Mansoura University 2(1): $53-66$.

22. Selim EM, Mosa AA \& El-Ghamry AM (2009). Evaluation of humic substances Fertigation through surface and subsurface drip irrigation systems on potato grown under Egyptian sandy soil conditions. Agric Water Manag 96: 1218-1222.

23. Sarir, MS, Sharif M. Zeb A \& Akhlaq M (2005). Influence of different levels of humic acid application by various methods on the yield and yield components of maize. Sarhad J Agric 21(1): 75-81.

24. Heng LC (1989). Influence of humic substances on P-sorption in Malaysian soils under rubber. J Natural Rubber Res 4(3): 186-194.

25. Muhammad D \& Khattak RA (2009). Growth and nutrient concentration of maize in pressmud treated saline-sodic soils. Soil \& Env 28: 145-155.

26. Hassan MA, El-Seifi SK, Omar EA \& Saif El-Deen UM (2005). Effect of mineral and bio-phosphate fertilization and foliar application of some micronutrients on growth, yield and quality of sweet potato "Ipomoea batata, L". Vegetative growth, yield and tuber characteristics. J Agric Sci, Mansoura Uni 30 (10): 6149-6166.

27. Hussain N, Khan AZ, Akbar H \& Akhtar $S$ (2006). Growth factors and yield of 
maize as influenced by phosphorus and potash fertilization. Sarhad $J$ Agric 22(4): 579-583.

28. Ghorbani S, Khazaei HR, Kafi M, Banayan \& Aval M (2010). The effect of adding humic acid to irrigation water on yield and yield components of corn. . Agric ecology 2: 123-131.

29. Haghighi S, Saki NT \& Lack SH (2013). Evalution of changes the qualitation \& quantitative yield of horse been (Vicia fabal) plant in the levels of humic Acid fertilizer. Life Sci J 8(3):

30. Azeem K, Khalil SK, Khan FU, Shah S, Qahar A, Sharif M \& Zamin M (2014). Phenology, yield and yield components of maize as affected by humic acid and Nitrogen. J Agric Sci 6(7): 286 -292.

31. Maqsood M, Abid AM, Iqbal A \& Hussain MI (2001). Effect of various rates of nitrogen and phosphorus on growth and yield of maize. Pak J Bio Sci 1: 19-20.

32. Canellas LP, Teixeira-Junior LRL, Dobbss LB, Silva CA, Medici LO, Zandonadi DB \& Facanha AR (2008). Humic acids cross interactions with root and organic acids. Annals Appl Bio 153: $157-166$.

33. Yoon-Ha Kim YH, Khan AL, Shinwari ZK, Kim DH, Waqas M, Kamran M \& Lee J (2012). Silicon treatment to rice (Oryza sativa L. CV 'Gopumbyeo') plants durin different growth periods and its effects on growth and grain yield. $P a k$ J Botany 44(3): 891-897.

34. Alam, SM \& Shah SA (2002). Phosphorus uptake and yield of wheat as influenced by integrated use of phosphatic fertilizers. Paper presented at $9^{\text {th }}$ International Congress of Soil Science Society of Pakistan held at NIAB, Faisalabad. 18-20.

35. Alam SM, Azam S, Ali S \& Iqbal M (2003). Wheat yield and P fertilizer efficiency as influenced by rate and integrated use of chemical and organic fertilizers. Pak J Soil Sci 22(2): 72-76.

36. El-Morsy AHA, Abdel-Fattah AE \& ElShal ZSA (2002). Effect of phosphate fertilizer and VA mycorrhizal inoculation on growth, tuber yield and quality of sweet potato. Proc Minia 1st Conf. for Agric Enuiron Sci, Minia Egypt, March 25-28: 1815-1827. 